\title{
El legado de Immanuel Wallerstein. In memoriam
}

\author{
Immanuel Wallerstein's Legacy. In memoriam
}

Yoan Molinero Gerbeau

IEGD-CSIC

El pasado 31 de agosto nos dejó Immanuel Morice Wallerstein, quién fuera padre de la teoría del sistema-mundo, gran impulsor de la corriente estructuralista y una mente privilegiada que se mantuvo activa e inquieta hasta el fin de sus días.

Wallerstein fue una rara avis, un tipo de investigador que hoy día está en peligro de extinción debido a la dictadura de las métricas, los índices y cuartiles de impacto que mandan en el mundo académico neoliberal. Y es que la incidencia de sus escritos y de su propia figura va más allá de lo cuantificable, pues su producción académica ha sido todo un legado para la humanidad.

Es posible situar su gran obra, la tetralogía mal traducida en castellano como "El moderno sistema mundial" (2016) al nivel de otros grandes tratados de las ciencias sociales históricas, como "El Capital" de Karl Marx, de quién tomó prestadas gran parte de las categorías que utilizó para producir las suyas propias. Sin embargo, para conocer la cosmología del sistema-mundo y la personalidad de quién lo acuñó, es necesario repasar su más que prolífica obra, compuesta tanto por los 500 comentarios que escribió de manera regular (2 al mes durante 20 años) para su propia web como por los más de 15 libros que editó y los numerosos artículos publicados en revistas y obras colectivas.

Si hoy utilizamos conceptos como las cadenas globales para entender la forma en la que los procesos de trabajo y producción transnacional están interconectados a nivel global, o definimos las relaciones internacionales como parte de un sistema único, organizado jerárquicamente, donde unas áreas denominadas como periféricas son sometidas por las áreas centrales para garantizar el proceso de acumulación global que las nutre, es gracias en gran parte a este autor. 
Ciertamente, sin la colaboración de otras grandes figuras del estructuralismo que nos abandonaron antes, como Giovanni Arrighi (2014) o Terence K. Hopkins (1982), Wallerstein no habría podido desarrollar su perspectiva hasta lo que es hoy día, pero quedará para la historia el hecho de que él fue el pionero que sentó las bases para romper con el tradicional alineamiento de la disciplina de Relaciones Internacionales ${ }^{1}$ con los poderes hegemónicos, ofreciendo una perspectiva crítica y radical de enorme impacto.

A veces calificado de economista, otras de historiador o sociólogo, lo cierto es que, aunque Wallerstein contribuyó con sus estudios a todas estas disciplinas, él fue un verdadero académico de las Relaciones Internacionales. No en vano su perspectiva fue, ante todo, un marco de lo internacional que aportó una explicación histórica, política y sociológica del funcionamiento del mundo desde el siglo XVI hasta la actualidad. Y es que el sistema-mundo no tenía como objetivo ser una teoría más de Relaciones Internacionales, su ambiciosa meta fue la de construir un paradigma que sirviera como macro-marco para entender la disciplina y así romper con la supuesta despolitización de los otros paradigmas el Realismo y el Liberalismo- señalando que la principal característica definitoria de las relaciones internacionales es la desigualdad.

El sistema-mundo se constituyó por lo tanto como un marco general, holístico, cuyas posibilidades de desarrollo son infinitas. Como suele decirse comúnmente en Relaciones Internacionales, los paradigmas son como gafas que el investigador escoge para ver la realidad internacional, por lo que uno de los grandes méritos de Wallerstein residirá en el hecho de habernos legado unas gafas cuya graduación evita el eurocentrismo y pone el foco sobre las desigualdades globales.

Para elaborar su perspectiva, Wallerstein tomó como referencia los estudios de Braudel (1976), principalmente en lo que respecta al concepto de la longue durée, una perspectiva temporal basada en definir los tiempos históricos en base a la duración de las macro estructuras, y al concepto de la economía-mundo, un análisis que trascendía el marco estatal para hablar de la conformación de "amplia(s) zona(s) geográfica(s) entre la(s) que hubo una división del trabajo y por lo tanto un significativo intercambio interno de bienes básicos o esenciales, así como de flujos de trabajo y capital" (Wallerstein 2004: 23). Con ello,

${ }^{1}$ Relaciones Internacionales se escribe con mayúsculas cuando se refiere a la disciplina, y en minúscula cuando se refiere a dinámicas de tipo internacional. Tal como señalan Brown y Ainley "Relaciones Internacionales es el estudio de las relaciones internacionales" (2011: 1). 
desarrolló una teoría donde la expansión de las primeras economías-mundo, áreas de intercambio capitalista que condicionaban el comportamiento transnacional de los actores involucrados en ellas, a lo largo de fases históricas de acumulación, acabaron conformando al capitalismo como un sistema global, es decir un sistema-mundo (marcando, con la utilización del sufijo "-mundo" su intención de seguir la tradición braudeliana).

Así, él mismo definió el sistema-mundo como "una zona espacio-temporal que atraviesa múltiples unidades políticas y culturales representando una zona integrada de actividad e instituciones que obedecen ciertas normas sistémicas" (Wallerstein 2004: 17) regidas por la persecución constante e incesante de una acumulación infinita. A nivel global, este proceso se rige por la misma lógica de la fábrica, tal como la señaló Marx en El Capital, pues "así como el capitalismo conlleva $[. .$.$] la apropiación de plusvalía de un propietario hacia un trabajador,$ [...] también [conlleva] una apropiación de plusvalía de toda la economía-mundo hacia áreas centrales" (2000a: 86). Ello quiere decir que el sistema-mundo es un sistema desigual, basado en la explotación que los actores radicados en las áreas centrales (donde quedan apropiados los procesos de acumulación) llevan a cabo sobre aquellos localizados en la periferia global. Esta perspectiva, heredera principalmente de los trabajos impulsados por Raúl Prebisch en la CEPAL durante los años $50 \mathrm{y}$, sobre todo, de la Teoría de la Dependencia, caracterizará definitivamente al concepto del sistema-mundo: un sistema global (el sistema capitalista) que rige las relaciones internacionales, caracterizadas por el sometimiento y la explotación que las áreas centrales imponen sobre las áreas periféricas, con el objetivo de impulsar el infinito proceso de acumulación.

Este marco tendrá así un impacto decisivo en el Tercer Mundo, pero también impulsará la aparición de numerosas escuelas críticas que, a lo largo de las áreas centrales, desarrollarán estudios que profundicen en los cimientos y el funcionamiento del sistema-mundo. Como su propio autor indicó, se trata de una perspectiva, incluso una posición intelectual, cuyos límites la alejaban de ser una doctrina infalible, por ello el propio Wallerstein propuso contribuir a expandirla y también criticarla, con el objetivo de que creciera y trascendiera su propia figura.

El resultado es neto, no solo se han producido miles (incluso millones) de artículos e investigaciones que han usado la perspectiva del sistema-mundo, sino que se han editado revistas, como Review, que el propio Wallerstein fundó en 1976 o el Journal of World-Systems Research dirigido por Chase-Dunn. 
La trascendencia del trabajo de Immanuel Wallerstein es incluso mayor que su aporte teórico, pues además de fundar el Fernand Braudel Center, centro pionero de investigaciones estructuralistas, fue presidente de la International Sociological Association (ISA) entre 1994 y 1998, demostrando que las teorías de corte crítico/neomarxista podían también ocupar espacios hegemónicos. En ese sentido, el hecho de defender posiciones eminentemente de corte socialista y antiimperialistas cobra más valor teniendo en cuenta que desarrolló la mayor parte de su carrera en los Estados Unidos.

Si a día de hoy los enfoques estructuralistas gozan de una gran robustez es gracias a Wallerstein, cuya escuela seguirá trabajando durante décadas su perspectiva o desarrollando otras nuevas, como por ejemplo la ecología-mundo de Jason W. Moore (2015). Quiénes dedicamos nuestra actividad a ello, seguiremos considerando la academia como un espacio privilegiado para contribuir al cambio social y a la construcción de realidades basadas en una mayor justicia y equidad, tal como el gran maestro Wallerstein hizo a lo largo de su vida. Gracias por tu trabajo, que la tierra te sea leve.

\section{REFERENCIAS}

ARRIGHI, G. (2014). El largo siglo XX. Madrid: Akal.

BRAUDEL, F. (1976). El Mediterráneo y el mundo Mediterráneo en la época de Felipe II. Ciudad de México: Fondo de Cultura Económica.

BROWN, C., \& AINLEY, K. (2009). Understanding International Relations. Basingstoke and New York: Palgrave Macmillan.

MOORE, J. W. (2015). Capitalism in the Web of Life: Ecology and the Accumulation of Capital. New York: Verso.

WALLERSTEIN, I. (2016). El moderno sistema mundial I. La agricultura capitalista y los orígenes de la economía-mundo europea en el siglo XVI. Tres Cantos: Siglo XXI.

WALLERSTEIN, I. (2004). The Modern World-System as a Capitalist WorldEconomy: Production, Surplus Value, and Polarization. In I. Wallerstein (Ed.), World-Systems Analysis. An Introduction (pp. 23-41). Durham: DukeUniversityPress.

WALLERSTEIN, I. (2000). The essential Wallerstein (The New Pr). New York 
SOCIOLOGÍA HisTÓRICA (SH)

Yoan Molinero Gerbeau es doctor en Ciencias Políticas y Relaciones Internacionales. Investigador asociado en el Instituto de Economía, Geografía y Demografía del CSIC e Investigador en el Instituto Universitario de Estudios sobre Migraciones de la Universidad Pontificia de Comillas. 